\title{
Dedicatoria
}

\section{A la memoria de don Julián Colamar Al futuro del pueblo de Caspana}

En la parte mía como presidente del pueblo de Caspana, voy a agradecer en primer lugar a Mauricio, que ellos por lo menos nos han tomado en cuenta a nosotros como comunidad. Llegaron a Caspana y ellos hicieron el trabajo no como ellos querían, ellos fueron respetuosos con nosotros y nos pidieron permiso para poder hacer esto, y a la vez nos pidieron que nosotros estuviéramos con ustedes y así para que nosotros veamos las cosas, qué es lo que están haciendo ustedes. El secretario y yo nos hicimos el tiempo, que el tiempo para nosotros es muy importante, pero hicimos un esfuerzo de acompañarlos y venir hasta acá, y así nosotros aprendimos algo, no voy a decir que aprendí mucho porque bien saben ustedes que a mí me cuesta entrar el primer día, pero ya un poco más allá, va entrando en confianza y va agarrando ideas. Uno ve, como ser nosotros ahora en Caspana, que algunas partes en realidad, yo siendo de allá propio, ni siquiera lo sabía. Entonces yo lo encuentro muy maravilloso que ustedes me hayan dado una oportunidad para hacer un alumbramiento de qué cosas hay dentro del pueblo de nosotros. Ahora yo estoy muy contento con ustedes que hemos participado, igualmente acá...Yo estoy muy maravillado y me voy muy contento, me hubiera gustado estar hasta el final pero como nosotros tenemos nuestros quehaceres, nuestras ocupaciones, el trabajo allá, la fiesta religiosa, nosotros como dirigentes de allá, así que nosotros no lo podemos acompañar... Estoy muy contento de ustedes y muy agradecido.

Palabras de despedida de don Juan Anza, Presidente de la Comunidad Indígena de Caspana, el día 13 de agosto de 1999 en el Museo Arqueológico R.P. Gustavo Le Paige, San Pedro de Atacama.

Con el permiso de cada uno de ustedes los presentes y especialmente del joven Mauricio y su comitiva que lo acompaña. En primer lugar, quiero decirles algo referente a lo que por lo menos compartir con ustedes. Algunos desde Caspana hasta acá hasta este minuto voy a decir y algunos que recién han llegado, y también me voy conscientemente que conociendo a las personas, no sé muy perfectamente bien sus nombres, pero bueno, al final y al cabo lo voy a averiguar. Para mí ha sido una cosa tan valiosa poder decirles de cada uno de ustedes, he trabajado todos estos días a contar del lunes hasta hoy, de las cosas de las cuales yo especialmente aprendí de ustedes como vuelvo a repetir, conocí también los sitios que tal vez de repente, les contaba, no conocía, qué es lo que significaban y qué contenían los sitios ar- 
queológicos, entonces para mí es una satisfacción y un honor y un orgullo, a la vez, haber conocido todas estas cosas. Y la manera de compartir de cada uno, sus personas, y también a quienes dirigen la comitiva, que han sido unas personas tan amables puedo decir y de buena voluntad para tomar en cuenta en primer lugar a la comunidad de Caspana. Nosotros de alguna manera como ustedes lo observan en un punto de vista, seamos lo que seamos una clase por decir, somos dirigentes a los cuales debemos velar por nuestro pueblo y por nuestra comunidad. Entonces nosotros para podernos llevar también de parte de ustedes el conocimiento a nuestra comunidad yo creo que lo más pronto posible de darle a conocer lo que hemos aprendido de ustedes y lo que ustedes nos han enseñado, ya sea tanto en los mismos sitios dentro de ayer y hoy, la discusión que ustedes tuvieron dentro de cada uno como profesores o qué se yo, lo comparten, lo discuten de una manera tan clara para poder corregirse ambos, y saber ambos lo que a cada uno le pertenece y dónde les corresponde. Eso para mí me voy a ir bien conforme y contento y agradecido a la vez, de compar- tir, y espero que no sea ni la última ni la primera, yo estoy dispuesto a estar y seguir colaborando y cooperando tal vez siempre con ustedes, porque las cosas a mí me gustan y me ha gustado también decir, he trabajado también bastante tiempo como dirigente, ya sea en distintas organizaciones de mi pueblo de Caspana. Me ha gustado decir, trabajar y hacer el bien comunitario y el bien de cada poblador. No importa, como se dice en todas partes, que nos criticamos los unos a los otros, eso no importa... Por último, bueno, que más puedo decirles, solamente agradecerles y pedirles que siempre sigamos trabajando y ustedes también en conjunto, y en cada uno de sus destinos donde trabajan ustedes. Que el Todopoderoso los bendiga a cada uno de ustedes y que sea el todo, que muchas gracias, y será hasta otra oportunidad. Gracias.

Palabras de despedida de don Bernardino Colamar, Secretario de la Comunidad Indígena de Caspana, el día 13 de agosto de 1999 en el Museo Arqueológico R.P. Gustavo Le Paige, San Pedro de Atacama. 